\title{
Review article: The meristem in indeterminate root nodules of Faboideae
}

\author{
Barbara Lotocka • Joanna Kopcińska • Monika Skalniak
}

Received: 2 September 2012 / Accepted: 14 January 2013 /Published online: 25 January 2013

(C) The Author(s) 2013. This article is published with open access at Springerlink.com

\begin{abstract}
In this review, the anatomy of indeterminate legume root nodule is briefly summarized. Next, the indeterminate nodule meristem activity, organization and cell ultrastructure are described in species with a distinct nodule meristem zonation. Finally, the putative primary endogenous factors controlling nodule meristem maintenance are discussed in the context of the well-studied root apical meristem (RAM) of Arabidopsis thaliana.
\end{abstract}

Keywords Meristem maintenance $\cdot$ Stem cells $\cdot$ Rhizobialegume symbiosis

\section{Introduction}

The soil bacteria collectively termed rhizobia are able to induce the formation of special symbiotic organs, the root nodules, in the root hair extension zone of their host plants. Initial stages of the symbiosis involve complex processes of mutual recognition, root colonization and invasion which occur nearly simultaneously in the rhizosphere, at the rhizoplane and within the host root (Foucher and Kondorosi 2000). Outside of the root, rhizobia recognize the host plant's presence and migrate towards its roots. Next at the rhizoplane they colonize the emerging root hairs and penetrate their wall to become internalized by the host. At the same time, the competent cells of the root are activated by transmissible rhizobial morphogens, the Nod factors, and reenter the cell cycle. The activated cells are located just

B. Łotocka $(\bowtie) \cdot$ J. Kopcińska $\cdot$ M. Skalniak

Department of Botany, Faculty of Agriculture and Biology,

Warsaw University of Life Sciences - SGGW,

Nowoursynowska 159,

02-776 Warsaw, Poland

e-mail: blotocka@gmail.com beyond the rhizodermis (Genisteae) or in the pericycle and in the inner cortical layers (Trifolieae, Vicieae), depending on the host species. The activated cells undergo ordered mitoses and thus form a nodule primordium. If a particular primordium is not aborted via the nodule number autoregulation mechanism (Mortier et al. 2012), the maintenance of primordial mitotic activity in a predetermined position leads later on to the establishment of a nodule meristem. In numerous Fabaceae, the nodule meristem is of indeterminate nature. Potentially, such meristems are able to function through the whole existence of the relevant organ. The socalled indeterminate nodules (the correct term "nodules with indeterminate growth meristem" would be awkward) occur in Lathyrus, Pisum and Vicia (tribe Vicieae; classification after Sprent 2001), Medicago, Melilotus and Trifolium (Trifolieae), Robinia (Robinieae), Astragalus (Galegae), and also in Genisteae as Lupinus, Genista, Sarothamnus, Cytisus, to name just the most common genera.

\section{Anatomy of indeterminate nodules}

Generally, the root nodule is built up of three types of tissues: meristematic, vascular and parenchymatic ones; the latter tissues can be grouped into a few types of cortical parenchyma and the very distinct, centrally-located bacteroid-containing tissue. In mature indeterminate nodules (Fig. 1a-c), five developmental zones are recognized (Timmers et al. 2000; Vasse et al. 1990) resulting from prolonged activity of the nodule meristem:

- nodule meristem (zone I), which produces cells for the formation of all nodule tissues and for its selfmaintenance; the meristem is rhizobia-free in most species,

- infection zone (=infection thread penetration zone, zone II), where the cells cease divisions due to the penetration 


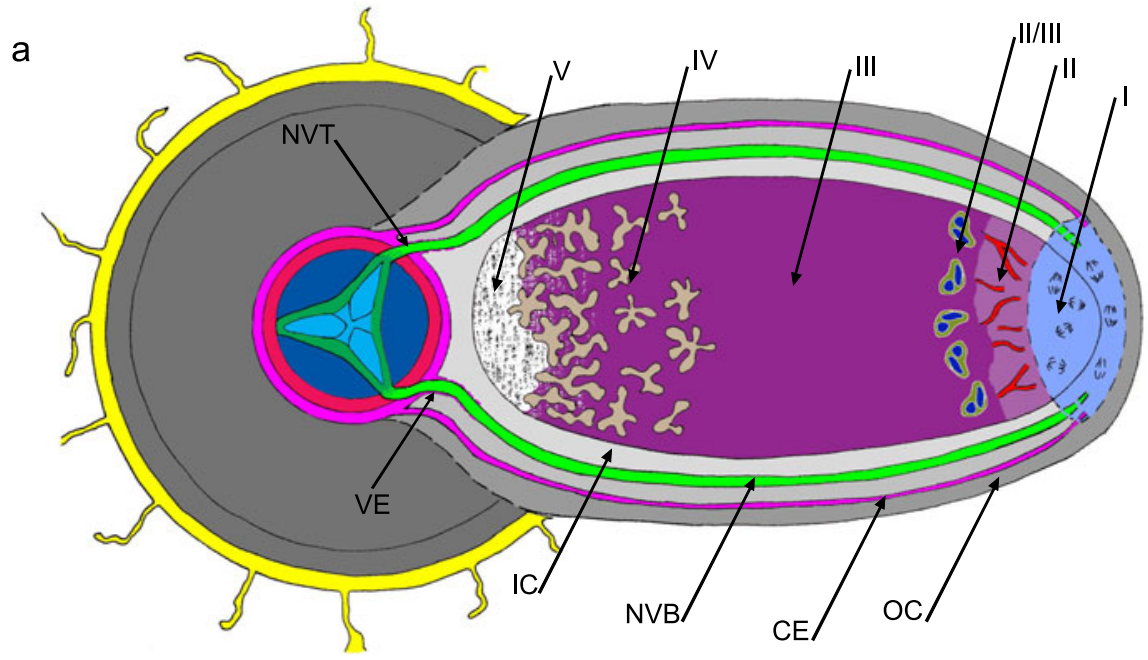

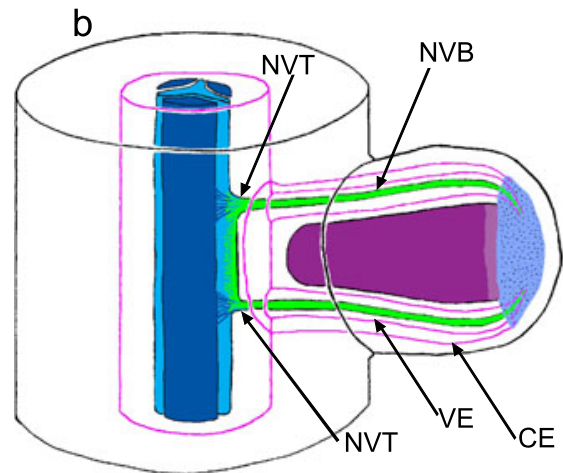

Fig. 1 a-c Representations of cylindrical root nodules. Fig. 1a: Generalized anatomical features of a nodule that developed from an infection opposite a phloem pole: I - nodule meristem is uninfected, discrete cell domains add cells for growth of various nodule tissues, II - infection thread penetration zone, II/III - interzone II/III rich in large amyloplasts, III - $\mathrm{N}_{2}$ fixation zone, IV - senescence zone, $\mathrm{V}$ - saprophytic zone. Zones II-V represent stages of differentiation of the bacteroid-containing tissue. This tissue is surrounded with cortical layers: parenchymatous outer cortex (OC) of non-specialized cells, cortical endodermis (CE), which is a monolayer of lignified cells that together with specialized cells located within the inner cortex (IC) contribute to the maintenance of microoxic conditions necessary for nitrogenase activity. CE is continuous with the root endodermis. Vascular system of the nodule consists of inner cortex-located vascular bundles (NVB) that bifurcate from a vascular trace (NVT), which connects the nodule with the root vascular tissues. The bifurcation, which usually occurs close to the base of the bacteroidcontaining tissue, has been omitted in the drawing to show that apical NVB portions are connected with the nodule meristem. NVT and NVB differ in ultrastructure and genesis since NVB extension is effected by the nodule meristem without participation of the root pericycle. NVT and

of infection threads; here the rhizobia are released from infection threads and after endocytotic internalization differentiate into bacteroids,

- interzone II/III, where a rapid increase in starch content occurs; here the bacteroid-containing tissue undergoes the final stages of differentiation,

- $\mathrm{N}_{2}$ fixation zone (=differentiated zone, zone III), here the bacteroids enclosed within perisymbiont membranes

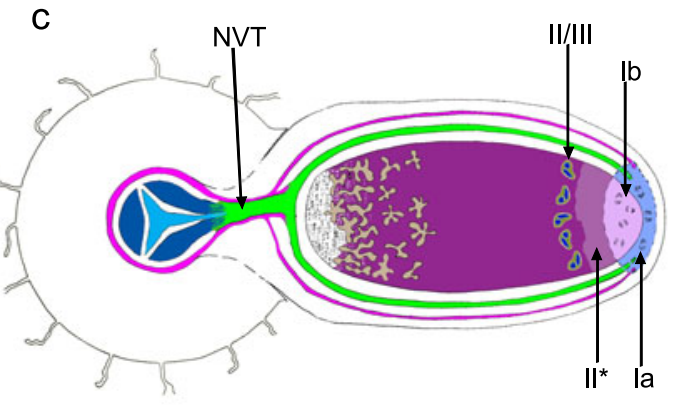

NVB are sheathed in a vascular endodermis (VE, not to the scale) continuous with the root endodermis and of similar ultrastructure. The details of NVT and NVB histological structure are not shown and the root anatomy is not labeled. Fig. $1 \mathrm{~b}$ : The connection between root stele and nodule vascular system of a type common in Vicieae and frequent in Trifolieae (nodule vasculature in sagittal view, abbreviations as in Fig. 1a). Such connections are formed in the nodules that develop from an infection opposite a xylem pole. The nodule vascular trace (NVT) that originates from the pericycle at the root protoxylem is short and somewhat extended axially; at its proximal and distal side two vascular bundles (NVB) differentiate, their bifurcation is effected by the nodule meristem (not shown). Fig. 1c: Generalized anatomical features in a nodule variant typical for Genisteae. Ia - non-infected portion of nodule meristem which adds cells for growth of nodule cortical tissues and extends the $\mathrm{NVB}, \mathrm{Ib}$ - infected portion of nodule meristem which adds cells for growth of bacteroid-containing tissue, $\mathrm{II}^{*}$ - differentiation zone in bacteroid-containing tissue. Note a distinct NVT, which is the result of the origin of bacteroid-containing tissue from a sub-rhizodermal cell. Bifurcation of nodule vascular bundles omitted as in $1 a$. Fig. $1 \mathrm{~b}$ adapted from Bond (1948)

derived from the plasma membrane of the host cell (symbiosomes) actively catalyse the reduction of $\mathrm{N}_{2}$ to $\mathrm{NH}_{4}^{+}$,

- senescence zone (zone IV), where the in legumes from the inverted repeat-lacking clade (IRLC) terminallydifferentiated bacteroids are no longer able to fix nitrogen and where once the bacteroids are degraded, the host cell enters a degradation pathway, 
- saprophytic zone (zone V), where dead cells of the host are colonized by rod-shaped rhizobia originating from the nodule apoplast (mostly from infection threads). These rhizobia, after a period of saprotrophic life in the host apoplast, return to the soil after nodule decomposition.

All the above mentioned zones are parts of the so-called central zone or central tissue, which corresponds to the bacteroid-containing tissue of the root nodule, with the exception of the nodule meristem. The central zone is surrounded with multilayered and functionally-complex cortical tissues containing a system of bifurcating vascular bundles. It is not the authors' intention to elaborate on the subject of nodule anatomy. The papers by Brown and Walsh (1994, 1996), Guinel (2009a, b), Pate et al. (1969) or Łotocka $(2008 \mathrm{~b}, \mathrm{c})$ are recommended to a reader interested in the details of the nodule cortical or vascular tissue.

\section{Organization and ultrastructure of indeterminate nodule meristem}

\subsection{Cylindrical nodules of Vicieae, Trifolieae, Robinieae and Galegae}

Typical indeterminate nodules are ovoid in shape due to the apical location of theirs meristems (Fig. 1). The ovoid shape is lost in older nodules, which are branched as a result of meristem division. The distal face of the meristem is protected by a non-specialized thin parenchymatic tissue (Figs. 2, 3). Meristem width and thickness depend on the species and the current growth ratio of the nodule. The meristem is devoid of intercellular spaces and composed of cells that are small, rich in cytoplasm and with numerous small vacuoles (e.g. Astragalus sinicus in Figs. 2, 3) and Łotocka et al. (1997) and Newcomb (1981).
Within the nodule meristem, the provascular meristems are distinct (the authors hesitate to name them procambial strands, as they differ from typical procambial strands, such as those found close to the shoot apical meristem; e.g. McGahan 1955); they allow the elongation of the nodule vascular bundles in accordance with nodule growth. Their cells differ from the other meristematic cells in their elongated shape and radial arrangement around the nodule longitudinal axis (Figs. 3, 4, 5). When examined in longitudinal section, the meristematic apices of nodule bundles taper rapidly to a few founder cells (Fig. 3) located within the lateral part of the nodule meristem.

Ultrastructurally, the cells of a cylindrical nodule meristem are not atypical in comparison to cells of other meristems (Newcomb 1981). As such, they have thin primary walls, and their organelles are few and in an undifferentiated state. Their nucleoplasmic index (the quotient of the nuclear volume divided by the cytoplasm volume) is relatively high. Depending on the host plant, the vacuolar side of tonoplast may be associated with osmiophilic globules and it has been proposed that such globules are of phenolic origin (Nielson and Griffith 1978).

In older nodules of numerous host species, the meristem divides. How this occurs remains to be studied, but the visible result is the presence of non-infected, differentiating cells where the median part of the meristem used to be (Fig. 6). The meristem is "bisected" by these cells and because the mitotic activity in each "half" is maintained, two independently growing meristems arise. In time, their activity results in the bifurcation of the nodule (Figs. 7, 8). This phenomenon may occur repeatedly leading to fan-like or coralloid nodule shape (Corby 1981; Corby et al. 1983) depending on the orientation of the successive meristem divisions.

\subsection{Genisteae: lupinoid nodules}

Lupinus luteus and other lupines evidently contrast with the above description of root nodule meristem, with respect to

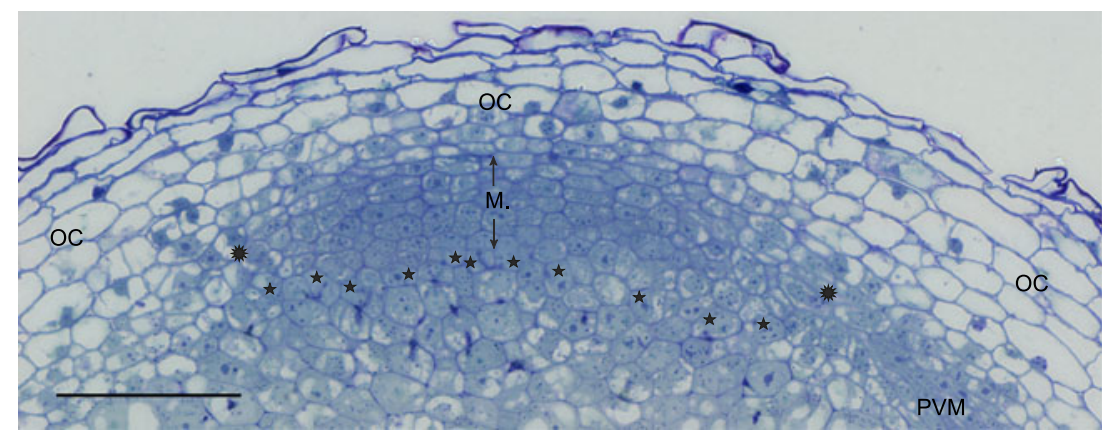

Fig. 2 Meristem in indeterminate cylindrical root nodule of Astragalus sinicus. Cells marked with asterisks were recently penetrated by infection threads which are visible in the section. These cells adjoin the proximal boundary of the zone I. The meristem (M) thickness is indicated with arrows and its width with rosettes. Provascular meristem
(PVM) is diagonally cut, its apex is beyond this section. The parenchymatic outer cortex (OC) protects the meristem. Semithin section stained with azure a and methylene blue, bright field photograph. Bar represents $100 \mu \mathrm{m}$ 
Figs. 3, 4, 5 Provascular meristems (rosettes) are an integral part of the nodule meristem (M). Fig. 3: Astragalus sinicus root nodule apex. Asterisks - vascular endodermis layer, large arrows - founder cells of provascular meristem. Fig. 4, 5: two transversal sections of the same nodule of Trifolium repens, the second one is cut close to the proximal face of the nodule meristem. Double arrowheads - layer of differentiated cortical endodermis. Common labels: OC - outer cortex, arrowheads - infection threads in the cells adjoining nodule meristem, white rosettes - differentiating cells of bacteroid-containing tissue. Semithin sections stained with azure a and methylene blue, bright field photograph. Bars represent 100,300 , and $300 \mu \mathrm{m}$, respectively
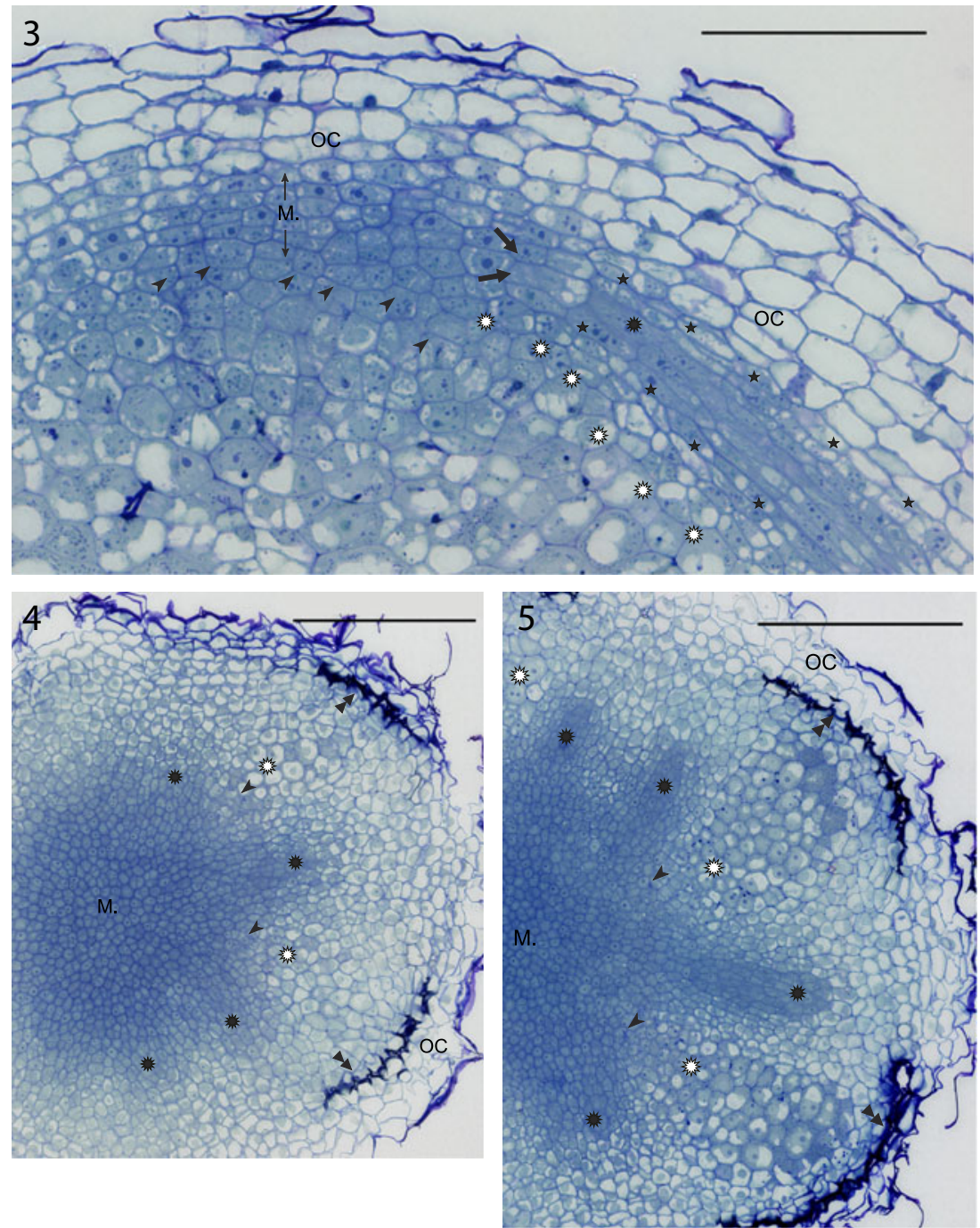

both meristem formation and meristem organization and ultrastructure. In lupinoid nodule primordia ca. 10 days post inoculation, the infected cells located distally and centrally differentiate while lateral cells remain meristematic. Thus, the lateral (in relation to the bacteroid-containing tissue) position of the nodule meristem is established (Łotocka et al. 2000), to be maintained during the next stages of nodule functioning. At this stage, the meristem has a ring-like shape and entirely encircles the differentiating bacteroid-containing tissue. As the bacteroid-containing tissue expands, the meristem cells differentiate locally in several points in coordination with the developing nodule vasculature; thereafter, the single ring-like nodule meristem is divided into several lateral meristems (Lotocka 2008b; c). The number of these meristems equals the number of vascular bundles in a young nodule, but the number of meristems maintained throughout a particular nodule depends on the growth conditions affecting this nodule, including the space available for nodule growth on a root. If the nodule develops in a root portion devoid of other nodules, all the initial meristems (ca. 6) grow and may divide in due time resulting in a dozen or so meristems in a $2-3$ months old nodule. In such a nodule, the meristems produce bacteroidcontaining tissue lobes of similar size and the nodule expands in every direction, gradually encompassing the root. However, if the nodule is located in close vicinity to another one, its mitotic activity ceases in meristems located within "colliding" distance of neighboring nodule. A single meristem may be maintained in a nodule developing within a dense nodule cluster, and in extreme cases, the meristematic growth may cease entirely in nodules completely surrounded by neighboring ones. For obvious reasons, a similar phenomenon does not occur in cylindrical nodules.

In $L$. luteus nodules, the nodule meristem consists of 2-4 layers of outer non-infected cells and inner infected ones. The thickness of the non-infected part of the meristem is rather constant, and the thickness of the infected one depends on the nodule age, growth conditions of the particular meristem, and plant fitness. The divisions of the nodule meristem infected cells (and their subsequent differentiation) result in the expansion of the bacteroid-containing 

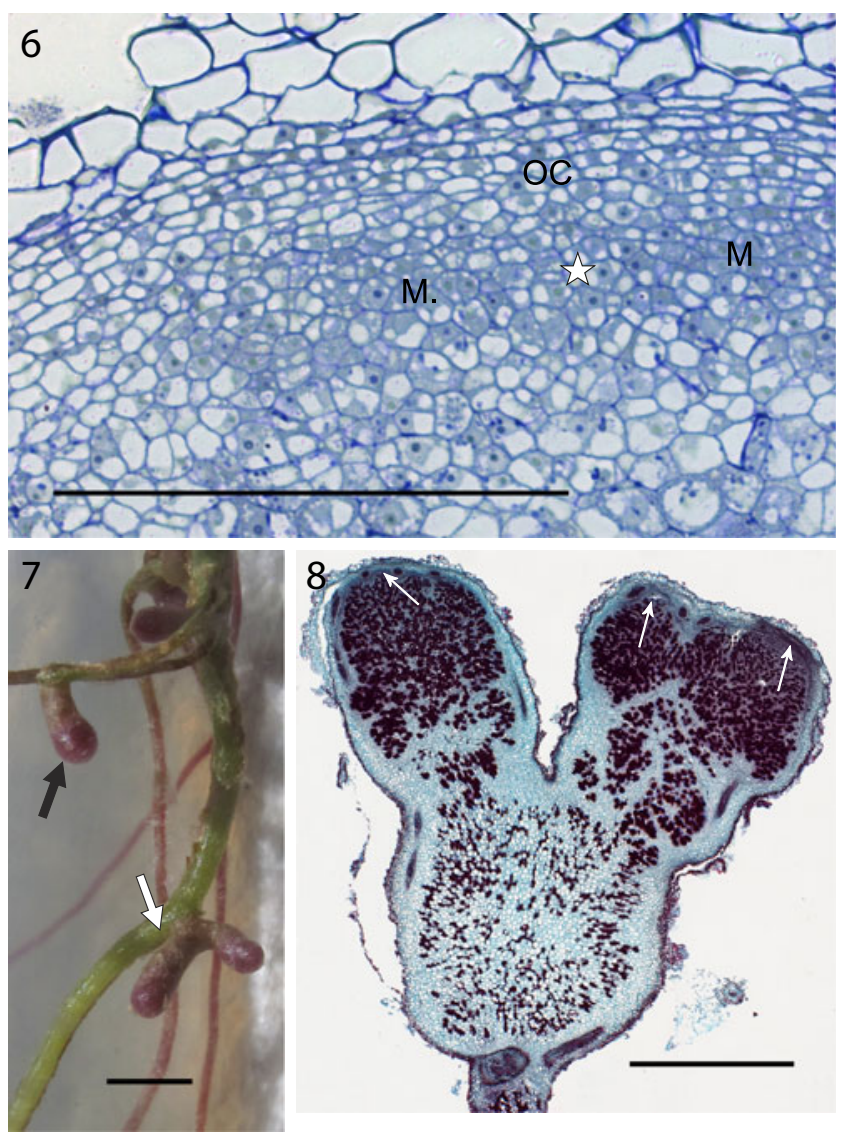

Figs. 6, 7, 8 Division of nodule meristem and resulting growth of the nodule. Fig. 6 and 8: Robinia pseudoacacia, 13 weeks after inoculation; 7: Genista tinctoria, 8 weeks after inoculation (dark coloration of the nodules and roots is due to anthocyanins present in some individuals of this species). $O C$ - outer cortex, $M$ or narrow white arrow nodule meristem, white asterisk - location of differentiating cells between meristems, black arrow - non-branched root nodule, white arrow - branched nodule. Fig. 6: semithin section stained with azure a and methylene blue, bright field photograph. Fig. 8: paraffin section stained with safranin and fast green, bright field photograph. Bars represent $300 \mu \mathrm{m}, 2 \mathrm{~mm}, 1 \mathrm{~mm}$, respectively

tissue. The divisions of non-infected cells lead to the growth of a multilayered nodule cortex, in concert with the increase of the volume of the bacteroid-containing tissue. The noninfected part of the nodule meristem is integrated with the apical (meristematic) parts of the nodule vascular bundles (Lotocka 2008b; c).

The yellow lupine nodule meristem contains cells with varying levels of ploidy $(2 \mathrm{C}-8 \mathrm{C})$ and the frequency of the cells exhibiting higher DNA levels tends to decrease as the nodule ages (Olszewska and Legocki 1989). In that study, it was not determined whether the non-infected and infected zones of the nodule meristem differ with regard to the distribution of cell nuclei of different ploidy levels. The zones, however, differ visibly as to their ultrastructure (based on the authors' own observations and Golinowski et al. 1987, 1992). Non-infected meristem cells are vacuolated, and electron-dense phenolic deposits and globuli are abundantly associated with the inner face of their tonoplast. Within the cytoplasm of both meristematic cell types, numerous long cisternae of rough endoplasmic reticulum stand out. The cisternae often fold around a cytoplasmic domain containing visibly more ribosomes. Ribosomeenriched domains are more frequent in the infected cells. The formation of such folds may be the preliminary stage of the development of protein-containing vacuoles. Such vacuoles, one per cell, are a very conspicuous feature of mature bacteroid-containing tissue cells in L. luteus (Golinowski et al. 1987). The most characteristic component of infected cell ultrastructure is the symbiosome. In distal meristematic cells, the number of symbiosomes is small. In the central sections of such cells undergoing mitosis, usually up to a dozen symbiosomes are visible at the karyokinetic spindle poles. Proportionally to the distance of the infected cell to the meristem "apex", the number of symbiosomes increases rapidly due to their multiplication. Within the symbiosomes present in the meristematic cells, bacteroids are usually elongated, of a slightly irregular shape, with ribosomes uniformly distributed within their cytoplasm and an electron-dense, fibrillar genophore. Another constant feature of meristematic infected cells in Lupinus is the occurrence of a non-identified material surrounded by a group of several symbiosomes. The material consists of electron-dense grains of blurred outline different from ribosomes (see in Łotocka 2008a, Figs. 57 and 82). These may represent cytosolic complexes of host cell enzymes, supplying some substances (proteins?) necessary for symbiosome functioning (divisions?). These structures are unique for lupines and not observed beyond their nodule meristem. In the cells soon to cease meristematic activity (located on the proximal side of the meristem), the vacuolar system changes in a contrasting manner dependent on the cell developmental programme: i) in the infected cells, all vacuoles are eliminated with the exception of a single vacuole filled with fine-fibrillar material; ii) the non-infected meristematic cells become more vacuolated.

\subsection{Genisteae: cylindrical nodules}

Within the Genisteae tribe, genera other than lupines, produce cylindrical nodules. The meristems of their nodules exhibit a mixture of traits characteristic of the apical meristem of typical cylindrical nodules like those of Astragalus and of the lateral meristem of lupinoid nodules. In temperate Genisteae, specifically in Sarothamnus scoparius (Sajnaga et al. 2001; Łotocka 2008a), Genista tinctoria (Kalita et al. 2006; Łotocka 2008a), Lembotropis nigricans, Chamaecytisus ratisbonensis and Ulex europaeus (Łotocka 2008a) the nodule meristem takes a course of development similar to that seen in Trifolium (compare Fig. 9 in this paper and Fig. 11 in Łotocka et al. 1997), resulting in its apical position in 
the mature nodules. However, its organization resembles that seen in Lupinus sp. with two distinct zones of meristematic cells (Fig. 10). The 3-4 layered outer zone of noninfected cells adjoins the inner part of the meristem, which consists exclusively of infected cells.

Within the non-infected meristematic layer, the inner and outer cells differ in the prevailing plane of division. The inner cells (i.e. the cells that adjoin the infected portion of the meristem) divide anticlinally within the distal part of the meristem, and periclinally within the lateral part. The outer non-infected meristematic cells divide periclinally and produce a protective layer of parenchyma that covers the distal
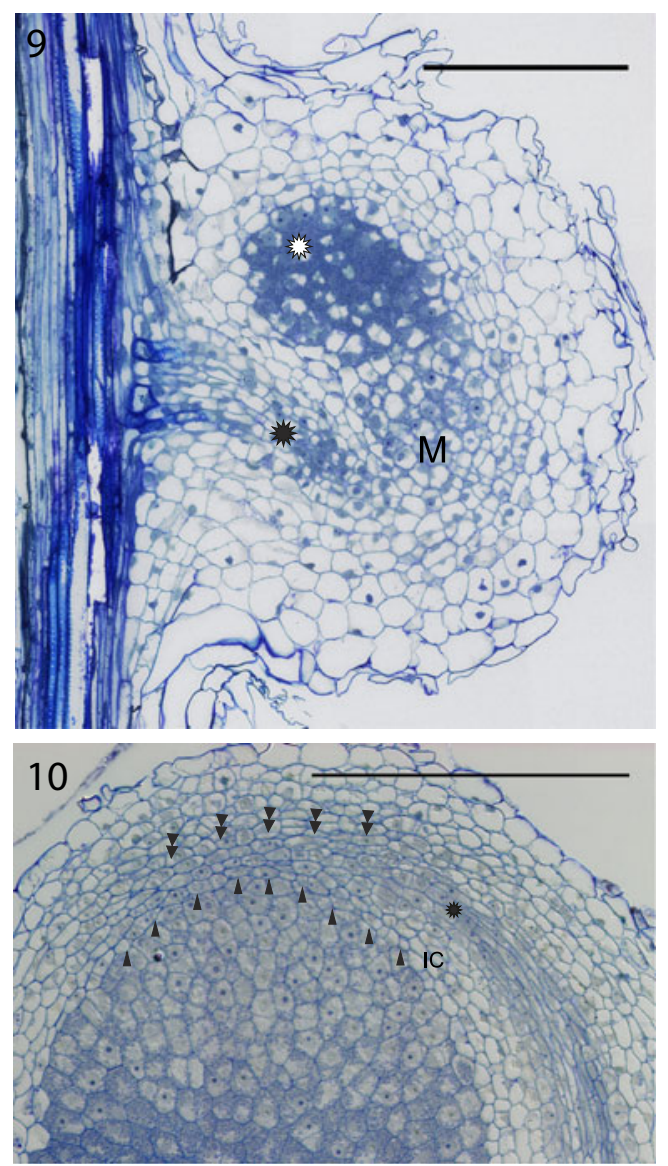

Fig. 9, 10 Cylindrical nodules of Genisteae. Fig. 9: the nodule primordium in Ulex europaeus. The meristem (M) of a nodule primordium is located laterally to the differentiating infected cells (white rosette). The meristematic vascular connection (black rosette) extends from the root stele towards the primordium meristem. Fig. 10: nodule meristem in Lembotropis nigricans. Arrowheads point to the cell walls at the interface of the outer (non-infected) and inner (infected) cells of the nodule meristem. Since Genisteae do not form infection threads, the proximal face of the meristem is impossible to define precisely on a light micrograph. Double arrowheads point to the outer limit of the meristem, which is recognizable due to the presence of intercellular spaces. IC - inner cortex, rosette - provascular meristem. Semithin sections stained with azure a and methylene blue, bright field photograph (Fig. 9) or differential interference contrast (DIC; Fig. 10). Bars represent $300 \mu \mathrm{m}$ face of the meristem. Within the infected part of the nodule meristem, the cells divide in various planes. However, in some species transverse divisions prevail resulting in a file-like arrangement of daughter cells. Often, spatulate nodules are observed with a flattened apex. In such nodules, the meristem is very wide and its infected part is already separated into longitudinal lobes with layers of non-infected cells. This organization of the apical portion of the nodule is typical for the early stage of nodule branching. As in Lupinus, the meristematic parts of the nodule vascular bundles are integrated with the non-infected layers of nodule meristem. In rapidly growing nodules, meristematic cells of both types (infected and non-infected) are little vacuolated within the distal part of the meristem. The proximal meristematic cells usually contain more vacuoles, which in $S$. scoparius and $U$. europaeus (but not in the other species studied) accumulate on the proximal side of the cells. The non-infected and infected meristematic cells are ultrastructurally similar to the correspondent cells in L. luteus, with the exception of the above-mentioned features unique to lupine.

As shown, much is known about the developmental anatomy and ultrastructure of the indeterminate nodule meristem. But how is this meristematic activity maintained by the host plant?

\section{QC and stem cells maintenance in RAM of Arabidopsis thaliana}

By definition, the meristem of indeterminate growth type functions through the whole existence of the relevant organ. However, the indeterminate growth is just a possibility that is not implemented to the full extent or perpetually. The activity and also the very existence of an indeterminate meristem is controlled by multitude of factors that may be roughly divided into endogenous (i.e. transcription factors, signal peptides, phytohormones) and exogenous (growth conditions: light, temperature, nutrients availability, herbivores etc). Of primary importance are the endogenous factors and among them the "most primary" are those involved in the maintenance of a meristem organizing centre and stem cells.

Most data on indeterminate meristem control have been provided by studies on the shoot apical meristem (SAM) and root apical meristem (RAM) of Arabidopsis thaliana. In SAM and RAM of this species, initial cells (stem cells) and relevant organizing centers were identified long ago. Much knowledge has been amassed concerning the mechanism of equilibrium maintenance between contrasting functions of these indeterminate meristems - self-renewal of stem cells and production, by the very same stem cells, of daughter cells for histogenesis. Central to the mechanism is the organizing center (OC) in the SAM and its equivalent in the RAM - the quiescent center (QC). Specifically in RAM of 
A. thaliana, the QC is surrounded by a monolayer of stem cells for root stele, root cortex, lateral root cap+rhizodermis or columella (see the recent excellent review by Cederholm et al. 2012). The disappearance of the QC, which can be induced experimentally (e.g. by ablation), results in the loss of transmissible signals that "inform" stem cells about their identity; further, due to the loss of stem cell identity, RAM cells undergo differentiation and the meristem disappears. Among the regulatory elements crucial for the maintenance of QC and RAM stem cells, the best-studied are the transcription factors SHORT ROOT (SHR; Benfey et al. 1993; Lucas et al. 2011), PLETHORA1 and PLETHORA2 (PLT1, 2; Aida et al. 2004), SCARECROW (SCR; DiLaurenzio et al. 1996; Sabatini et al. 2003), WUSCHEL-related homeobox (WOX; Sarkar et al. 2007) and several peptides from the CLAVATA-LIKE (CLE) family (Casamitjana-Martínez et al. 2003). Another key element of the mechanism is the information carried by the polar auxin flow from the older parts of the root, facilitated by the differential location of auxin efflux proteins of PIN family (Cederholm et al. 2012). The overlapping activity of these factors provides positional information for the stem cell niche, which is necessary for the maintenance of stem cell identity.

\section{Meristem maintenance in indeteminate nodules: answers wanted}

In stark contrast to the RAM control mechanism, the data on functional aspects of root nodule meristem are very sparse, mostly due to the scarcity of relevant molecular studies.

After analysis of the cell lineages in the serial sections of nodule meristem, it is possible to trace the stem cells of the nodule vascular bundles (Łotocka 2008b). However such an analysis does not allow researchers to identify the stem cells of the bacteroid-containing tissue or the nodule cortical layers. This results from the fact that in the nodule meristem, the cell arrangement is not regular in contrast to that in the RAM, where the longitudinal cell lineages merge gradually to point at their stem cells. Therefore in the nodule meristem, the existence and location of a putative QC (or an organizing center of a different type) or stem cells must be investigated by molecular methods (i.e. specific expression of genes active in an $\mathrm{OC}$ or QC).

The structural resemblance between nodule meristem and RAM or SAM is low, but since numerous control elements were found to be common or very similar for both RAM and SAM (Sarkar et al. 2007; Stahl and Simon 2010), it may be assumed that during the evolution of rhizobia-legume symbiosis these elements were recruited to control indeterminate nodule meristem. Taking into consideration that different factors are crucial for the proper functioning of different portions of the RAM, i.e. QC, stem cells, their meristematic progeny and transitory cells exiting the meristem (Shishkova et al. 2008), it is reasonable to assume that the mechanism of indeterminate nodule meristem maintenance is no less complex than that of the RAM. As mentioned, the very fundamental factor for RAM is the existence of QC together with the surrounding stem cells. Therefore, the activity of genes influencing QC cell or stem cell identity is expected to be at the core of the nodule meristem maintenance mechanism, while the activity of genes controlling the cell cycle or influencing the switch between the meristematic/differentiating pathways may be crucial for the control of nodule meristem size.

\section{Symbiotic mutants}

Potentially, much knowledge could be gained from studies of nodule meristem maintenance in symbiotic mutants that are available in considerable number, e.g. mutants of Pisum sativum (e.g. Sidorova and Shumnyi 2003) or of the legume model species M. truncatula (Pislariu et al. 2012). However, papers seldom focus on the meristem of any nodules formed by the mutants and studies lack molecular "depth" aimed at the meristem. In numerous cases when a decrease or cessation of meristematic activity has been found in mutant nodules, the mutation affects not nodule meristem maintenance per se, but the nodule primordium stage (e.g. Lohar et al. 2006) or the process of nodule number autoregulation (e.g. Markwei and LaRue 1997).

Currently, a single mutant has been well described with a defect probably close to the core of nodule meristem control. The homeotic $P$. sativum mutant cochleata, in addition to exhibiting changes in leaf formation and fertility, produces dichotomously branching nodules (with nitrogen fixation activities not affected), and their nodule meristems form multiple structures resembling calli or lateral roots (Ferguson and Reid 2005). It is suggested that the defect consists of a loss of identity by the nodule meristem stem cells.

Another interesting mutant has been found in M. truncatula (Bright et al. 2005). In this species, a factor influencing the long-term function of the nodule meristem may be the product of the LATD gene. In latd mutants, the nodule meristem, as well as the RAM of tap root and lateral roots is gradually consumed. In contrast to what is seen in the cochleata mutant, in the nodules of the latd mutant rhizobia released from infection threads do not differentiate into bacteroids and consequently nitrogen fixation is severely affected. The LATD gene encodes a transporter belonging to the NRT1(PTR) family. Members of the NRT1(PTR) family transport nitrate, di- and tri-peptides (Tsay et al. 2007; Jeong et al. 2004), hormones (Kanno et al. 2012) and glucosinolates (Nour-Eldin et al. 2012), and M. truncatula NIP/LATD gene encodes a protein of unclear function 
in planta that demonstrates high-affinity nitrate transport in Xenopus laevis oocytes (Salehin et al. 2013). The transporter is expressed in RAM and root nodule meristem, but its function (or involvement in QC maintenance) is not known beyond its dependence on auxin, cytokinin and abscisic acid (Yendrek et al. 2010). Obviously, both the mutants mentioned above are promising but further studies are needed to determine the processes by which they affect nodule meristem function.

\section{Analysis of promoter activity}

An attempt to show the action of several promoters specifically active in QC and stem cells of $A$. thaliana in the root nodule meristem of M. truncatula was reported by Wan and collaborators in one of the chapters of his $\mathrm{PhD}$ thesis available on-line at the Wageningen University site http://edepot.wur.nl/ 44753 (Wan 2007). The promoters of WOX5, AtQC25 (QC marker 25; Sabatini et al. 1999), PLT1, PLT2 and SCR were used in the study. Vectors containing AtWOX5::GUS, AtQC25::GUS, AtPLT2::GUS and AtSCR ::GUS constructs were introduced into M. truncatula A17 through Agrobacterium rhizogenes-mediated transformation. Three weeks later, the resulting hairy roots were inoculated with Sinorhizobium meliloti 2011 to induce the development of nodules. All the mentioned $A$. thaliana promoters were found to be active in the nodule, specifically in the meristem cells positioned in a ring at the periphery of the meristem. Two domains of activity were recognized; one domain was located at the apices of the provascular meristems, and the other included nonprovascular peripheral meristem cells. The meristem apex was free of any detectable promoter activity. According to this source, the domains correspond to the nodule meristem QC but this seems doubtful for a few reasons. First, to use the term QC, the low frequency of mitoses has to be shown in the domains. Second, in these peripheral locations, the nodule meristem cells are already determined as to their developmental pathways (vascular, cortical or bacteroid-containing) and such developmental determination is a feature of stem cells rather than QC cells. Third, it is possible that the authors were examining senescent nodules which had slowed or already lost their meristematic activity. This doubt emerges from a lack of information, one wonders what was the age of the nodules examined and what was their nitrogen fixation status (i.e., their metabolic "fitness"). Any factors impairing nitrogen fixation efficiency increase senescence processes in the nodule (see e.g., Vance et al. 1980), including the loss of meristem function as in the case of nodules induced by defective rhizobia (see e.g., Hirsch et al. 1983). Despite all reservations, the work by Wan (2007) is a very important step towards understanding the root nodule meristem.

\section{Phytohormones}

Apparently, all meristem control points involve the action of phytohormones. It is important to remember that the origin of the phytohormones detectable in nodules is not known; furthermore it is unclear to what extent both partners in the symbiosis participate in the production of these phytohormones. These compounds can be imported via the vascular system from the other plant organs, they can be produced by the host within the nodule (meristem) and they can also be synthesized by the rhizobia (for the latter, see Pii et al. 2007). Both in nodule primordia and in mature nodules of Lupinus albus and M. truncatula, aldehyde oxidase (EC 1.2.3.1) activity was detected (Fedorova et al. 2005). This enzyme catalyzes the last stage of IAA biosynthesis. The activity was located in the nodule meristem of both species and also in the zone II of Medicago truncatula nodule (in Lupinus sp. nodules this zone is absent, as lupines do not form infection threads). By means of immunolocalization, high levels of IAA were shown in the same nodule zones. Presumably, auxin is at least synthesized in the nodule and this is performed by both partners of the symbiosis.

Both the presence of auxin and the direction of its transport (polar auxin flow), which per se carries positional information for the cells and participates in the creation of auxin distribution pattern, affects developmental processes. In A. thaliana, the polar auxin flow is achieved by means of asymmetric cellular location of AtPIN1, AtPIN2, AtPIN3, AtPIN4 and AtPIN7 proteins at the plasma membrane, where they act as auxin efflux proteins (Petrášek and Friml 2009). The differential distribution of various PINs within a meristem results in specific auxin distribution pattern. Nine PIN proteins (MtPIN1 to MtPIN10) are expressed in shoots and nodulating roots of $M$. truncatula, and the expression of MtPIN2 (an AtPIN2 homolog) is root-specific (Schnabel and Frugoli 2004). Huo et al. (2006) proved that MtPIN2 is present in the root nodule. The Arabidopsis homolog of this plasma-membrane protein is located in the apical portion of the RAM protodermal cells and therefore mediates the upward flow of auxin to the elongation zone (Petrášek and Friml 2009). In the cortical layer of RAM cells, the location of AtPIN2 is reversed in proximal and distal portions of the meristem. Unfortunately, no data on the precise subcellular location of MtPIN2 are available yet. Also, there are no data on the occurrence of the other PINs in root nodules. A map of polar auxin transport within a root nodule similar to that known for RAM or SAM does not exist yet.

\section{Cell cycle control}

The maintenance of the nodule meristem involves also a control of the cell division ratio, as the mitotic activity of the 
stem cells has to be linked to the "fitness" of the plant and its ability to support nitrogen fixation. Thus, the activity of genes coding for proteins controlling the cell cycle has to be regulated in nodule meristem, including putative stem cells. In several legume species, cyclins are known that are differentially expressed during nodule organogenesis (Foucher and Kondorosi 2000; Kondorosi et al. 2002; Roudier et al. 2003). In L. luteus, Cyc3 and Cyc4 are active during the formation of nodule primordia, and later $\mathrm{Cycl}$ and $C y c 2$ are active in the meristem of mature nodules (Deckert et al. 1996; Jeleńska et al. 2000). In M. truncatula a cyclin was identified which may have nodule-specific activity: CycD3 was localized to nodule zones I and II, and its expression in zone I suggests a role in nodule meristem maintenance (Foucher and Kondorosi 2000). Concerning the search for stem cells in the nodule meristem, the studies cited here are not precise enough to discriminate among different portions of this meristem.

\section{Conclusion}

The knowledge concerning molecular organogenesis and molecular organography of $A$. thaliana SAM and RAM is considerable and, although far from complete, a point has been reached where scientists obtain more answers rather than generate more questions. It is time to use this knowledge to investigate apical meristems of different species and less standard meristems. The model legume M. truncatula seems ideal as the next species to be investigated in depth, with its open RAM type (Heimsch and Seago 2008), in contrast to the closed RAM type of $A$. thaliana, and its ability to form unique symbiotic organs. The most promising way to understand the persistence of the nodule meristem is to test the activity of primary control factors known from A. thaliana apical meristems.

Acknowledgments This work as well as the participation in the ISS Congress was financed by National Science Centre grant NN303 797240 .

Open Access This article is distributed under the terms of the Creative Commons Attribution License which permits any use, distribution, and reproduction in any medium, provided the original author(s) and the source are credited.

\section{References}

Aida M, Beis D, Heidstra R, Willemsen V, Blilou I, Galinha C, Nussaume L, Noh Y-S, Amasino RM, Scheres B (2004) The PLETHORA genes mediate patterning of the Arabidopsis root stem cell niche. Cell 119:109-120

Benfey PN, Linstead PJ, Roberts K, Schiefelbein JW, Hauser MT, Aeschbacher RA (1993) Root development in Arabidopsis: four mutants with dramatically altered root morphogenesis. Development 119:57-70

Bond L (1948) Origin and developmental morphology of root nodules of Pisum sativum. Bot Gaz 109:411-433

Bright LJ, Liang Y, Mitchell DM, Harris JM (2005) The LATD gene of Medicago truncatula is required for both nodule and root development. Mol Plant Microbe In 18:521-532

Brown SM, Walsh KB (1994) Anatomy of the legume nodule cortex with respect to nodule permeability. Aust J Plant Physiol 21:49 68

Brown SM, Walsh KB (1996) Anatomy of the legume nodule cortex: species survey of suberisation and intercellular glycoprotein. Aust J Plant Physiol 23:211-225

Casamitjana-Martínez E, Hofhuis HF, Xu J, Liu C-M, Heidstra R, Scheres B (2003) Root-specific CLE19 overexpression and the sol1/2 suppressors implicate a CLV-like pathway in the control of Arabidopsis root meristem maintenance. Curr Biol 13:14351441

Cederholm HM, Iyer-Pascuzzi AS, Benfey PN (2012) Patterning the primary root in Arabidopsis. WIREs Dev Biol 1:675-691

Corby HDL (1981) The systematic value of leguminous root nodules. In: Polhill RM, Raven PH (eds) Advances in legume systematics. Kew Publishing, Kew, pp 657-669

Corby HDL, Polhill RM, Sprent JI (1983) Taxonomy. In: Broughton WJ (ed) Nitrogen Fixation. Volume 3. Legumes. Clarendon, Oxford, pp 1-35

Deckert J, Jeleńska J, Gwóźdź EA, Legocki AB (1996) The isolation of lupine cDNA clone coding for putative cyclin protein. Biochimie 78:90-94

DiLaurenzio L, Wysocka-Diller J, Malamy JE, Pysh L, Helariutta Y, Freshour G, Hahn MG, Feldmann KA, Benfey PN (1996) The SCARECROW gene regulates an asymmetric cell division that is essential for generating the radial organization of the Arabidopsis root. Cell 86:423-433

Fedorova EE, Redondo FJ, Koshiba T, Pueyo JJ, de Felipe MR, Lucas MM (2005) Aldehyde oxidase (AO) in the root nodules of Lupinus albus and Medicago truncatula: identification of AO in meristematic and infection zones. Mol Plant Microbe In 18:405413

Ferguson BJ, Reid JB (2005) Cochleata: getting to the root of legume nodules. Plant Cell Physiol 46:1583-1589

Foucher F, Kondorosi É (2000) Cell cycle regulation in the course of nodule organogenesis in Medicago. Plant Mol Biol 43:773-786

Golinowski W, Kopcińska J, Borucki W (1987) The morphogenesis of lupine root nodules during infection by Rhizobium lupini. Acta Soc Bot Pol 56:687-703

Golinowski W, Kopcińska J, Borucki W (1992) Morphometric characteristics of bacteroidal tissue in yellow lupine (Lupinus luteus L.) nodules. Acta Soc Bot Pol 61:307-318

Guinel FC (2009a) Getting around the legume nodule: I. The structure of the peripheral zone in four nodule types. Botany 87:1117-1138

Guinel FC (2009b) Getting around the legume nodule: II. Molecular biology of its peripheral zone and approaches to study its vasculature. Botany 87:1139-1166

Heimsch C, Seago JL Jr (2008) Organization of the root apical meristem in angiosperms. Amer J Bot 95:1-21

Hirsch AM, Bang M, Ausubel FM (1983) Ultrastructural analysis of ineffective alfalfa nodules formed by nif::Tn5 mutants of Rhizobium meliloti. J Bacteriol 155:367-380

Huo X, Schnabel E, Hughes K, Frugoli J (2006) RNAi phenotypes and the localization of a protein::GUS fusion imply a role for Medicago truncatula PIN genes in nodulation. J Plant Growth Regul 25:156-165

Jeleńska J, Deckert J, Kondorosi É, Legocki AB (2000) Mitotic B-type cyclins are differentially regulated by phytohormones and during yellow lupine nodule development. Plant Sci 150:29-39 
Jeong J, Suh SJ, Guan C, Tsay YF, Moran N, Oh CJ, An CS, Demchenko KN, Pawlowski K, Lee Y (2004) A nodule-specific dicarboxylate transporter from alder is a member of the peptide transporter family. Plant Physiol 134:969-978

Kalita M, Stępkowski T, Łotocka B, Małek W (2006) Phylogeny and nodulation genes and symbiotic properties of Genista tinctoria bradyrhizobia. Arch Microbiol 186:87-97

Kanno Y, Hanada A, Chiba Y, Ichikawa T, Nakazawa M, Matsui M, Koshiba T, Kamiya Y, Seo M (2012) Identification of an abscisic acid transporter by functional screening using the receptor complex as a sensor. Proc Natl Acad Sci USA 109:9653-9658

Kondorosi A, Cebolla A, Charon C, Foucher F, Györgyey J, Johansson C, Roudier F, Sousa C, Vinardell JM, Crespi M, Kondorosi É (2002) Cell cycle control in root nodule organogenesis. In: Pedrosa FO, Hungria M, Yates G, Newton WE (eds) Nitrogen fixation: From molecules to crop productivity. Kluwer Academic Publishers, Dordrecht, pp 223-226

Lohar DP, Sharopova N, Endre G, Penuela S, Samac DA, Town CD, Silverstein KAT, VandenBosch KA (2006) Transcript analysis of early nodulation events in Medicago truncatula. Plant Physiol 140:221-234

Łotocka B (2008a) Anatomia rozwojowa i ultrastruktura brodawek korzeniowych o nieograniczonym wzroście i jej specyfika u roślin z plemienia Genisteae [Developmental anatomy and ultrastructure of indeterminate root nodules and their specificity in genisteans]. Wydawnictwo SGGW, Warszawa

Łotocka B (2008b) Vascular system within developing root nodules of Lupinus luteus L. 1. Juvenile stage. Acta Biol Cracov Bot 50:79-88

Łotocka B (2008c) Vascular system within developing root nodules of Lupinus luteus L. 2. Differentiated nodules. Acta Biol Cracov Bot 50:89-103

Łotocka B, Kopcińska J, Golinowski W (1997) Morphogenesis of root nodules in white clover. I. Effective root nodules induced by the wild type of Rhizobium leguminosarum biovar. trifolii. Acta Soc Bot Pol 66:273-292

Łotocka B, Kopcińska J, Górecka M, Golinowski W (2000) Formation and abortion of root nodule primordia in Lupinus luteus L. Acta Biol Cracov Bot 42:87-102

Lucas M, Swarup R, Paponov IA, Swarup K, Casimiro I, Lake D, Peret B, Zappala S, Mairhofer S, Whitworth M, Wang J, Ljung K, Marchant A, Sandberg G, Holdsworth MJ, Palme K, Pridmore T, Mooney S, Bennett MJ (2011) SHORT-ROOT regulates primary, lateral, and adventitious root development in Arabidopsis. Plant Physiol 155:384-398

Markwei CM, LaRue TA (1997) Phenotypic characterization of sym21, a gene conditioning shoot-controlled inhibition of nodulation in Pisum sativum cv. Sparkle. Physiol Plant 100:927-932

McGahan MW (1955) Vascular differentiation in the vegetative shoot of Xanthium chinense. Amer J Bot 42:132-140

Mortier V, Holsters M, Goormachtig S (2012) Never too many? How legumes control nodule numbers. Plant Cell Env 35:245-258

Newcomb W (1981) Nodule morphogenesis and differentiation. In: Giles KL and Atherly AG (eds) Biology of the Rhizobiaceae. Int Rev Cytol, suppl. 13 pp 247-298

Nielson AJ, Griffith WP (1978) Tissue fixation and staining with osmium tetroxide: the role of phenolic compounds. J Histochem Cytochem 26:138-140

Nour-Eldin HH, Grube Andersen T, Burow M, Madsen SR, Jørgensen ME, Olsen CE, Dreyer I, Hedrich R, Geiger D, Halkier BA (2012) NRT/PTR transporters are essential for translocation of glucosinolate defence compounds to seeds. Nature 488:531-534

Olszewska MJ, Legocki AB (1989) Changes in DNA content during rhizobial nodule development in Lupinus luteus L. I. Cytophotometry and autoradiography. Biol Zentralbl 108:221-230

Pate JS, Gunning BES, Briarty LG (1969) Ultrastructure and functioning of the transport system of the leguminous root nodule. Planta 85:11-34
Petrášek J, Friml J (2009) Auxin transport routes in plant development. Development 136:2675-2688

Pii Y, Crimi M, Cremoese G, Spena A, Pandolfini T (2007) Auxin and nitric oxide control indeterminate nodule formation. BMC Plant Biol 7:21

Pislariu CI, Murray D, Wen J, Cosson V, Muni RRD, Wang M, Benedito A, Andriankaja A, Cheng X, Jerez IT, Mondy S, Zhang S, Taylor ME, Tadege M, Ratet P, Mysore KS, Chen R, Udvardi MK (2012) A Medicago truncatula tobacco retrotransposon insertion mutant collection with defects in nodule development and symbiotic nitrogen fixation. Plant Physiol 159:1686-1699

Roudier F, Fedorova EE, Lebris M, Lecomte P, Györgyey J, Vaubert D, Horvath G, Abad P, Kondorosi A, Kondorosi É (2003) The Medicago species A2-type cyclin is auxin regulated and involved in meristem formation but dispensable for endoreduplicationassociated developmental programs. Plant Physiol 131:1091-1103

Sabatini S, Beis D, Wolkenfelt H, Murfett J, Guilfoyle T, Malamy J, Benfey P, Leyser O, Bechtold N, Weisbeek P, Scheres B (1999) An auxin-dependent distal organizer of pattern and polarity in the Arabidopsis root. Cell 99:463-472

Sabatini S, Heidstra R, Wildwater M, Scheres B (2003) SCARECROW is involved in positioning the stem cell niche in the Arabidopsis root meristem. Genes Dev 17:354-358

Sajnaga E, Małek W, Łotocka B, Stępkowski T, Legocki AB (2001) The root-nodule symbiosis between Sarothamnus scoparius L. and its microsymbionts. Anton Leeuw 79:385-391

Salehin M, Huang YS, Bagchi R, Sherrier DJ, Dickstein R (2013) Allelic differences in Medicago truncatula NIP/LATD mutants correlate with their encoded proteins' transport activities in planta. Plant Signal Behav 8:0-1

Sarkar AK, Luijten M, Miyashima S, Lenhard M, Hashimoto T, Nakajima K, Scheres B, Heidstra R, Laux T (2007) Conserved factors regulate signalling in Arabidopsis thaliana shoot and root stem cell organizers. Nature 446:811-814

Schnabel EL, Frugoli J (2004) The PIN and LAX families of auxin transport genes in Medicago truncatula. Mol Genet Genomics 272:420-432

Shishkova S, Rost TL, Dubrovsky JG (2008) Determinate root growth and meristem maintenance in angiosperms. Ann Bot 101:319-340

Sidorova KK, Shumnyi VK (2003) A collection of symbiotic mutants in pea Pisum sativum L.: creation and genetic study. Russ J Genet 39:406-413

Sprent JI (2001) Nodulation in legumes. Royal Botanic Gardens, Kew

Stahl Y, Simon R (2010) Plant primary meristems: shared functions and regulatory mechanisms. Curr Opin Plant Biol 13:53-58

Timmers ACJ, Soupéne E, Auriac MC, de Billy F, Vasse J, Boistard P, Truchet G (2000) Saprophytic intracellular rhizobia in alfalfa nodules. Mol Plant Microbe Interact 13:1204-1213

Tsay YF, Chiu CC, Tsai CB, Ho CH, Hsu PK (2007) Nitrate transporters and peptide transporters. FEBS Lett 581:2290-2300

Vance CP, Johnson LEB, Halvorsen AM, Heichel GH, Barnes DK (1980) Histological and ultrastructural observations of Medicago sativa root nodule senescence after foliage removal. Can J Bot 58:295-309

Vasse J, de Billy F, Camut S, Truchet G (1990) Correlation between ultrastructural differentiation of bacteroids and nitrogen fixation in alfalfa nodules. J Bacteriol 172:4295-4306

Wan X (2007) Analyses of nodule meristem persistence and ENOD40 functioning in Medicago truncatula nodule formation. Chapter 4: The Medicago root nodule meristem has two peripheral stem cell domains that resemble the root meristem stem cell domain. $\mathrm{PhD}$ thesis, Wageningen University, pp 69-87

Yendrek CR, Lee Y-C, Morris V, Liang Y, Pislariu CI, Burkart G, Meckfessel MH, Salehin M, Kessler H, Wessler H, Lloyd M, Lutton H, Teillet A, Sherrier DJ, Journet E-P, Harris JM, Dickstein R (2010) A putative transporter is essential for integrating nutrient and hormone signaling with lateral root growth and nodule development in Medicago truncatula. Plant J 62:100-112 